OPEN ACCESS

Citation: Anoop Puthuparampil Balan, Aloor Jose Robi, Ginu Joseph (2020) Ophiorrhiza meenachilarensis, a new species of Rubiaceae from southern Western Ghats, India. Webbia. Journal of Plant Taxonomy and Geography 75(2): 231-236. doi: 10.36253/jopt-8508

Received: April 23, 2020

Accepted: July 14, 2020

Published: November 18, 2020

Copyright: (c) 2020 Anoop Puthuparampil Balan, Aloor Jose Robi, Ginu Joseph. This is an open access, peerreviewed article published by Firenze University Press (http://www.fupress. com/webbia) and distributed under the terms of the Creative Commons Attribution License, which permits unrestricted use, distribution, and reproduction in any medium, provided the original author and source are credited.

Data Availability Statement: All relevant data are within the paper and its Supporting Information files.

Competing Interests: The Author(s) declare(s) no conflict of interest.

Funding: This work was supported by Science and Engineering Research Board (SERB), Department of Science \& Technology, Government of India.

Editor: Riccardo M. Baldini

\section{Ophiorrhiza meenachilarensis, a new species of Rubiaceae from southern Western Ghats, India}

\author{
Anoop Puthuparampil Balan ${ }^{1, *}$, Aloor Jose Robi², Ginu Joseph ${ }^{2}$ \\ ${ }^{1}$ KSCSTE-Malabar Botanical Garden and Institute for Plant Sciences, Kozhikode, Kerala, \\ India \\ ${ }^{2}$ Department of Botany, Bishop Abraham Memorial College, Thuruthicad, Pathanamthit- \\ ta, Kerala, India \\ ${ }^{\star}$ Corresponding author. E-mail: anooppb01@gmail.com
}

\begin{abstract}
A new species of Ophiorriza (Rubiaceae) from southern Western Ghats, India is here described and illustrated. Ophiorriza meenachilarensis is similar to $O$. eriantha, from which it differs in its herbaceous habit (vs. shrubby habit), densely villous-hirsute stem (vs. pubescent-glabrous stem), entire stipule (vs. bifid stipule), short-peduncled cymes (vs. comparatively long-peduncled cymes), unscented flowers (vs. scented flowers) and corolla tube with a ring of hairs at the middle of the tube (vs. corolla tube without a ring of hairs). A detailed description, illustrations, ecological observations, and geographic distribution are provided.
\end{abstract}

Keywords: Ophiorrhizeae, Camptothecin, Kerala, Rubioideae, Vagamon hills.

\section{INTRODUCTION}

Ophiorriza L. is a predominantly herbaceous genus that belongs to the tribe Ophiorrhizeae, subfamily Rubioideae, Rubiaceae (Bremer and Manen 2000). It is a species-rich genus consisting of 318 species, one subspecies and five varieties (WCSPF 2019) chiefly distributed in wet tropical forests of South-East Asia, extending to Australia, New Guinea and the Pacific Islands (Darwin 1976; Chen and Taylor 2011). The genus is taxonomically complicated and has been less-studied by taxonomists except Darwin (1976), Lo (1990), Halford (1991), Deb and Mondal (1997) and Tao and Taylor (2011). Deb and Mondal (1997) revised the genus in the Indian subcontinent, and recognized 47 species and 9 varieties from India. Since Deb and Mondal (1997), seven species have been added to the flora of India (Ramamurthy and Rajan 1985; Khan et al. 1998; Hareesh et al. 2015a,b, 2017a,b, 2018). Western Ghats is one of the diversity centres of Ophiorrhiza species followed by the north-eastern Himalayas. Nearly 21 taxa are distributed in the evergreen forest of the Western Ghats (Deb and Mondal 1997; Nayar et al. 2014).

Ophiorrhiza species are commercially important as source of Camptothecin (CPT), a potential anticancer drug. Rajan et al. (2016) screened 11 species and 3 varieties of Ophiorrhiza from the southern Western Ghats and 
found that $O$. mungos L. (396.54 $\mu \mathrm{g} / \mathrm{g}$, dr. wt.) and $O$. rugosa Wall. var. angustifolia $(373.19 \mu \mathrm{g} / \mathrm{g}$, dr. wt.) are the two best known sources of CPT, while O. rugosa var. decumbens $(18.55 \mu \mathrm{g} / \mathrm{g}$, dr. wt.) and O. hirsutula (17.14 $\mu \mathrm{g} / \mathrm{g}$, dr. wt.) showed moderate contents of CPT.

While conducting floristic explorations in the Vagamon hills of southern Western Ghats, the authors came across a few populations of a densely hairy species of Ophiorrhiza growing in moist shady areas of an evergreen forest patch in Kottayam-Idukki districts border. After critical study and comparison with other species of Ophiorrhiza and scrutiny of literature, it turned out to be quite different taxa from known species hence described as new to science and illustrated here. Final author conducted systematic screening of CPT in the newly described species and found that the CPT level is zero.

Ophiorrhiza meenachilarensis Robi \& Balan, sp. nov. (Figures 1 and 2)

Type: India, Kerala, Kottayam district, Vagamon Hills, \pm 1000 m, 17 June 2018, A.J. Robi \& Anoop P. B. 16881 (holotype, MH!; isotypes, KFRI, MBGH!).

\section{Diagnosis}

Ophiorrhiza meenachilarensis shows similarities with the southern Western Ghats endemic species O. eriantha Wight, but differs by its herbaceous habit, villoushirsute indumentum on stem, leaves and inflorescence, unlobed stipules, unscented flowers, glabrous hypanthium, lanceolate, bristly calyx lobes, corolla tube with a ring of hairs within, basally inserted stamens, ovateorbicular style branches and areolate exotesta of the seeds with a number of tubercles.

\section{Description}

Erect herbs, $30-45 \mathrm{~cm}$ tall; stem unbranched or with a few branches, terete, densely villous-hirsute throughout; internodes $2-5 \mathrm{~cm}$ long. Stipules ovate, acuminate at apex, entire, $8-12 \times 3-4 \mathrm{~mm}$, bristly outside, caducous. Leaves in unequal pairs; petioles $1.2-3.5 \mathrm{~cm}$ long, densely hairy; leaf blades obovate-elliptic, 8-17.5 $\times$ 2.5-6 cm, attenuate at base, acuminate at apex, sometimes subfalcate, chartaceous, sparsely appressed pilose above, densely so beneath especially along the veins, margins hirsute, hairs up to $2.5 \mathrm{~mm}$ long; lateral veins 8-12 (-14) pairs, close, prominent beneath. Inflorescence axillary and terminal, a corymbose cyme, 1.5-2.5 $\mathrm{cm}$ across; peduncles $0.1-2 \mathrm{~cm}$ long at anthesis and 2-3 $\mathrm{cm}$ long at fruiting, stout, rusty villous. Flowers 1-1.2 $\mathrm{cm}$ long; bracts and bracteoles similar, linear-lanceolate, 6-8 $\times 0.7-1 \mathrm{~mm}$, bristly along margins and outside, persistent. Pedicels $1-2 \mathrm{~mm}$ long. Hypanthium obovoid, $0.8-1 \times 0.6 \mathrm{~mm}$. Disc bilobed, $0.4-0.5 \mathrm{~mm}$ tall, glabrous. Calyx lobes lanceolate, $2-2.5 \times 0.4-0.5 \mathrm{~mm}$, bristly outside. Corolla infundibuliform, hispid outside; tube 7-8 $\mathrm{mm}$ long, patent-pubescent outside, appressed pubescent and with a ring of hairs at the middle of the tube inside; lobes ovate-lanceolate, $2.5-3 \times 1.5-2 \mathrm{~mm}$, acutesubacuminate, shortly keeled. Stamens included, inserted at the base of corolla tube; filaments $1-1.5 \mathrm{~mm}$ long; anthers linear-oblong, $1.5-1.6 \times 0.4 \mathrm{~mm}$. Style filiform, as long as corolla tube, glabrous, lobes 2 , ovate-orbicular, $1 \times 0.8 \mathrm{~mm}$. Capsules obcordate in outline, $4-5 \times 6-7$ $\mathrm{mm}$, laterally compressed, hispid, green. Seeds many, irregularly angled, $c a 0.4 \times 0.3 \times 0.3$, brown; exotesta areolate, wall of the areoles with a number of tubercles.

\section{Etymology}

The specific epithet refers to the type locality in Kottayam district of Kerala state, where the Meenachilar River originates.

\section{Distribution and habitat}

This species is currently known only from the type locality, Vagamon hills, Kerala, India. It is growing in moist shady areas of evergreen forest at an elevation of \pm $1000 \mathrm{~m}$ altitude, in association with Chassalia curviflora Thwaites, Clidemia hirta (L.) D. Don, Ophiorrhiza pectinata Arn., Ophiorrhiza jacobii Hareesh, Salish, G. Joseph $\& \mathrm{M}$. Sabu, among other species.

\section{Phenology}

Flowering and fruiting during May to September.

\section{Conservation status}

Ophiorrhiza meenachilensis is so far known only from two collections at the type locality, Vagamon Hills of Western Ghats, with an extent of occurrence estimated to be less than $10 \mathrm{~km}^{2}$. Extensive field surveys are needed to assign appropriate threatened category of IUCN (2012), therefore it is classified as Data Deficient (DD) according to IUCN standards.

\section{Notes}

Ophiorrhiza meenachilarensis is similar to O. eriantha in its broad, elliptic, acuminate leaves, short, congested, more or less hairy, corymbose cyme, long, linear and persistent bracts and bracteoles and broadly infundibuliform corolla with spreading lobes. In addition to the diagnostic characters, the new species differs from the latter by its 

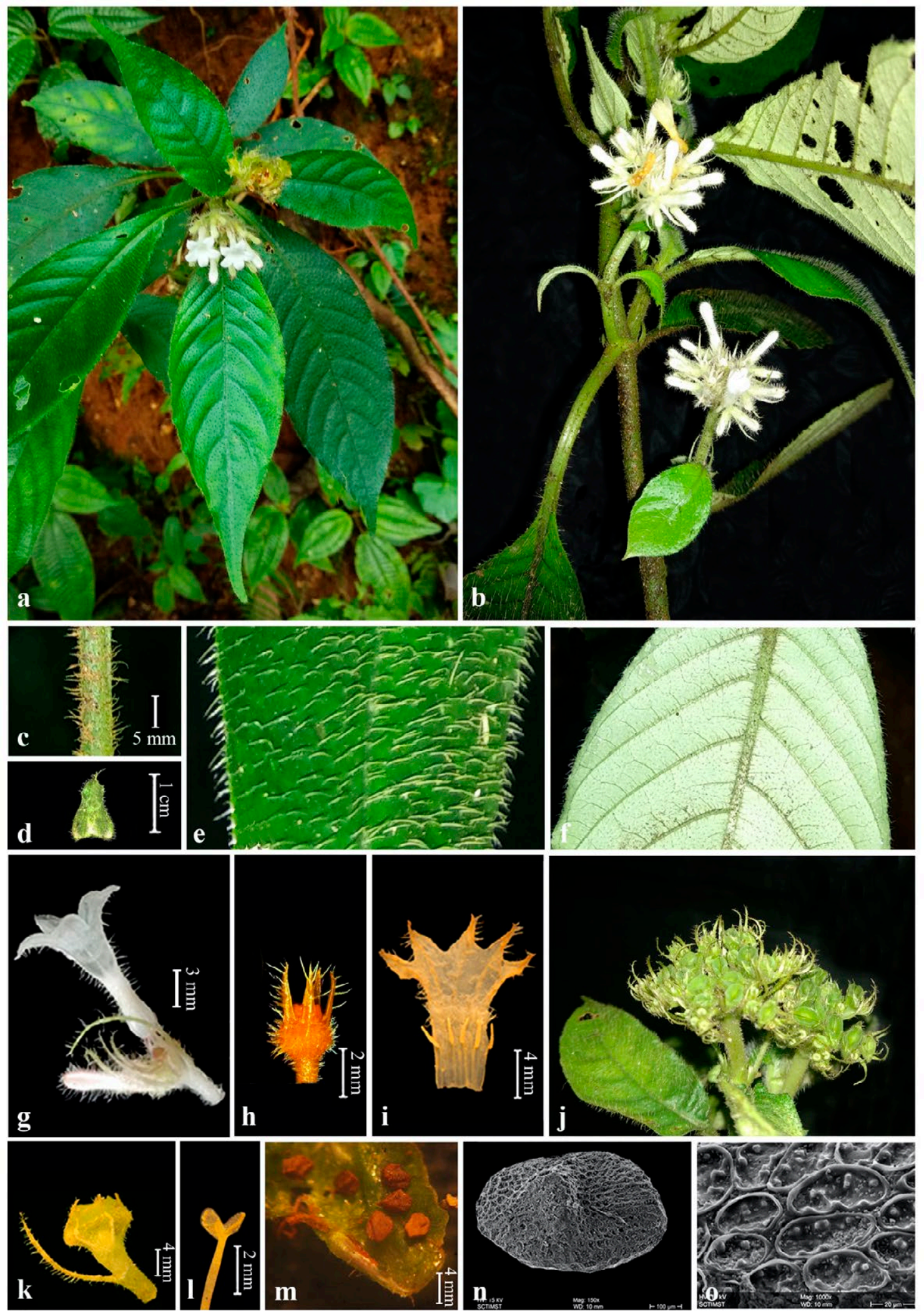

Figure 1. Ophiorrhiza meenachilarensis sp. nov. (a,b) Habit. (c) Stem. (d) Stipule. (e) Leaf: upper surface. (f) Leaf: Lower surface. (g) Flower. (h) Calyx. (i) Corolla split opened. (j) Infructescence. (k) Capsule. (l) Stigma. (m) Seeds. (n,o) SEM images of Seed. 


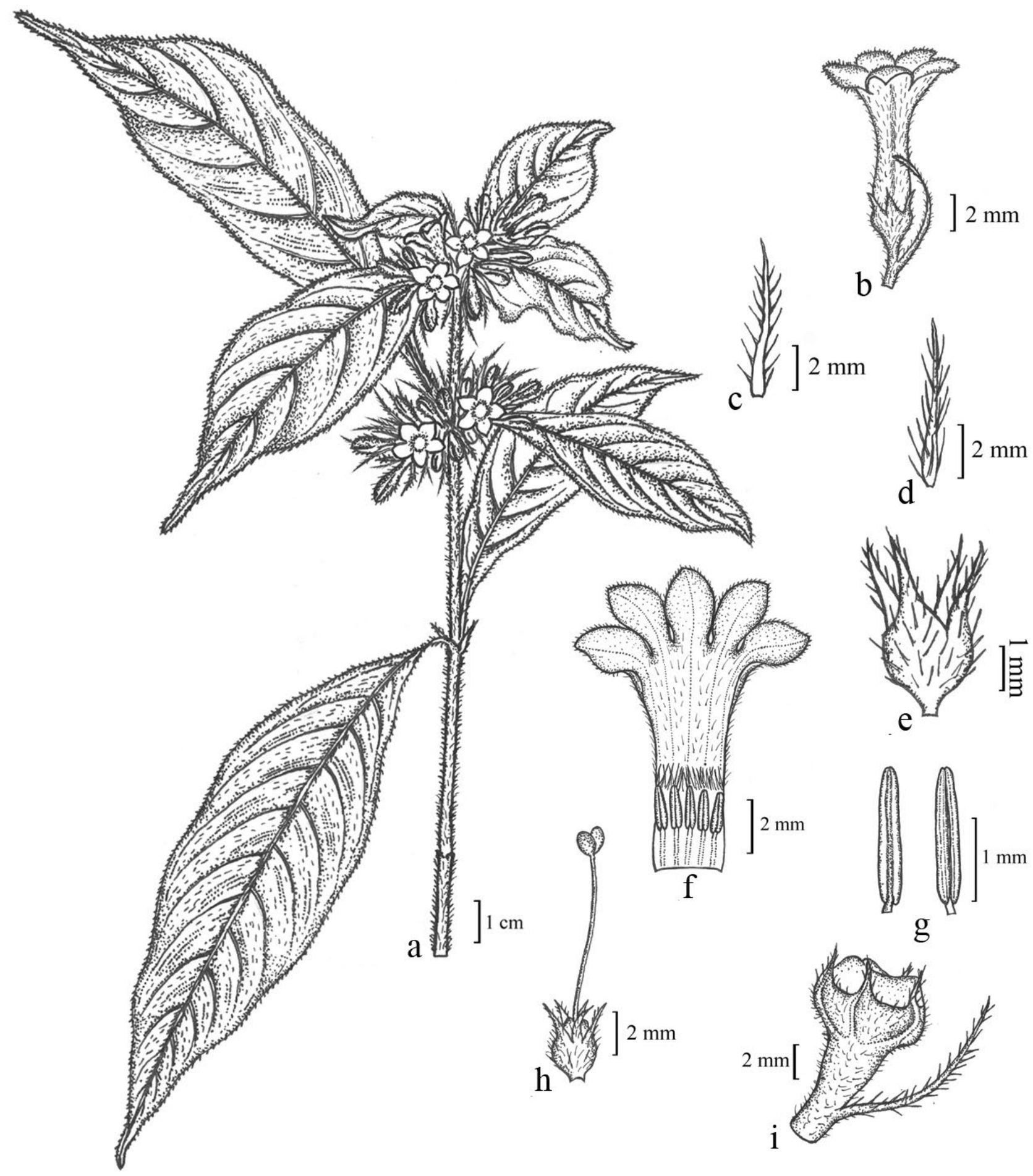

Figure 2. Ophiorrhiza meenachilarensis. sp. nov. (a) Habit. (b) Flower. (c) Bract. (d) Bracteole. (e) Calyx. (f) Split opened corolla. (g) Stamens. (h) Pistil. (i) Capsule. Drawn by Anoop P. Balan from A.J. Robi \& Anoop P. Balan 16881 (MBGH).

densely villous-hirsute stem (vs. pubescent-glabrous stem), ovate, acuminate, entire stipule (vs. lanceolate, bifid stipule), sparsely-densely pilose leaves with hirsute margins (vs. glabrous-puberulous leaves), up to $3 \mathrm{~cm}$ long peduncled cyme (vs. $4-5.5 \mathrm{~cm}$ long peduncled cyme), $1-1.2 \mathrm{~cm}$ long, unscented flowers (vs. 2.5-2.7 cm long, fragrant 
Table 1. Morphological comparison of Ophiorrhiza meenachilarensis. with O. eriantha.

\begin{tabular}{|c|c|c|}
\hline & O. meenachilarensis & O. eriantha \\
\hline Habit & Herb, $30-45 \mathrm{~cm}$ tall & Subshrub, $45-90 \mathrm{~cm}$ tall \\
\hline Stem & Densely villous-hirsute & Pubescent or glabrescent \\
\hline Stipule & $\begin{array}{c}0.8-1.2 \mathrm{~cm} \text { long, ovate, acuminate, entire at apex, bristly } \\
\text { outside }\end{array}$ & $\begin{array}{l}0.5-1.5 \mathrm{~cm} \text {, lanceolate, bifid at apex, puberulous-glabrous } \\
\text { outside }\end{array}$ \\
\hline Lamina & $\begin{array}{l}\text { Obovate-elliptic, sparsely appressed pilose above, densely } \\
\text { so beneath, margins hirsute }\end{array}$ & Elliptic-lanceolate, glabrous above, puberulous beneath \\
\hline Peduncle & $1.0-2 \mathrm{~cm}$ long at anthesis and $2-3 \mathrm{~cm}$ long at fruiting stage & $\begin{array}{c}0.3-4 \mathrm{~cm} \text { long at anthesis and } 4-5.5 \mathrm{~cm} \text { long at fruiting } \\
\text { stage }\end{array}$ \\
\hline Flowers & $1-1.2 \mathrm{~cm}$ long, unscented & $2.5-2.7 \mathrm{~cm}$ long, fragrant \\
\hline Bracts & $0.6-0.8 \mathrm{~cm}$ long, bristly & $10-17 \mathrm{~mm}$ long, pubescent \\
\hline Bracteoles & $0.6-0.8 \mathrm{~cm}$ long, bristly & 6-10 mm long, pubescent \\
\hline Hypanthium & Glabrous & Pubescent \\
\hline Calyx lobes & Lanceolate, $2-2.5 \mathrm{~mm}$ long, bristly outside & Subulate, $1.5-2 \mathrm{~mm}$ long, pubescent outside \\
\hline Corollas & $\begin{array}{l}\text { White, hispid outside, appressed pubescent inside with a } \\
\text { ring of hairs at the middle of the tube; tube } 6-8 \mathrm{~mm} \text { long }\end{array}$ & $\begin{array}{l}\text { Pinkish-white, villous outside, glabrous inside without a } \\
\text { ring of hairs; tube } 16-22 \mathrm{~mm} \text { long }\end{array}$ \\
\hline Stamens & $\begin{array}{l}\text { Inserted at the base of corolla tube; filaments } 0.5-1.0 \mathrm{~mm} \\
\text { long; anthers } 1.5-1.6 \mathrm{~mm} \text { long }\end{array}$ & $\begin{array}{l}\text { Inserted at the middle of the corolla tube; filaments } 2-2.75 \\
\text { mm long; anthers } 3-3.5 \mathrm{~mm} \text { long }\end{array}$ \\
\hline Style & As long as corolla tube & $1 / 4^{\text {th }}$ of the length of the corolla tube \\
\hline Style branches & Ovate-orbicular, obtuse & Lanceolate, acute \\
\hline Capsules & $4-5 \times 6-7 \mathrm{~mm}$, hispid & $2.5-3.25 \times 7-8.5 \mathrm{~mm}$, pubescent \\
\hline Seeds & $\begin{array}{c}0.4 \times 0.3 \mathrm{~mm} \text {, irregularly angled; exotesta areolate and the } \\
\text { wall of areole with tubercles }\end{array}$ & $\begin{array}{c}0.6 \times 0.5 \mathrm{~mm}, 4-6 \text { angled; exotesta areolate and the wall of } \\
\text { the areole with branched projections }\end{array}$ \\
\hline
\end{tabular}

flowers), glabrous hypanthium (vs. pubescent hypanthium), lanceolate, bristly calyx lobes (vs. subulate, pubescent calyx lobes), ovate-orbicular stigmatic lobes (vs. lanceolate, acute lobes) and areoles of exotesta with tubercles (vs. areoles with branched projections). A morphological comparison of the two species is summarized in Table 1.

\section{Additional specimens examined}

INDIA, Kerala, Kottayam district, Vagamon Hills, \pm $1000 \mathrm{~m}$ asl, 7 July 2018, Anoop P. B. 16896 (MBGH!).

\section{ACKNOWLEDGEMENTS}

The authors are grateful to the Director, KSCSTEMalabar Botanical Garden \& Institute for Plant Sciences, Kozhikode, Kerala, for all the facilities provided for this work. The constant encouragement and support of Dr. N.S. Pradeep, Sr. Scientist, MBGIPS, Kozhikode is also thankfully acknowledged. First author is indebted to Science and Engineering Research Board (SERB), Department of Science \& Technology, Government of India, for financial assistance through the project PDF/2016/001936. The second author is thankful to the Principal, Bishop Abraham Memorial College, Thuruthicad, for the facilities and support.

\section{REFERENCES}

Bremer B, Manen JF. 2000. Phylogeny and classification of the subfamily Rubioideae (Rubiaceae). Pl Syst Evol. 225:43-72. https://doi.org/10.1007/BF00985458

Chen T, Taylor, CM. 2011. Ophiorrhiza. In: Wu ZY, P.H. Raven (Eds.) Flora of China. Science Press, Beijing \& Missouri Botanical Garden Press, St. Louis. Vol. 19, p. 258-282.

Darwin, SP. 1976. The Pacific species of Ophiorrhiza L. (Rubiaceae). Lyonia. 1:48-101.

Deb DB, Mondal DC. 1997. Taxonomic revision of the genus Ophiorrhiza L. (Rubiaceae) in Indian subcontinent. Bull Bot Surv India. 39:1-148.

Halford DA. 1991. The genus Ophiorrhiza L. (Rubiaceae) in Australia. Austrobaileya. 3: 369-375. https://www. jstor.org/stable/41738777

Hareesh VS, Wu, L, Joe A, Sabu, M. 2017a. Ophiorrhiza meghalayensis (Rubiaceae: Ophiorrhizeae), a new species from Meghalaya, North-EastIndia. Phytotaxa. 307:297-300. http://dx.doi.org/10.11646/phytotaxa.307.4.8

Hareesh VS, Joe A, Sabu M. 2017b. Ophiorrhiza debiana (Rubiaceae, Rubioideae), a new species from NorthEast India. Phytotaxa. 309:291-294. http://dx.doi. org/10.11646/phytotaxa.309.3.13 
Hareesh VS, Salish MJ, Wu L, Joseph G, Sabu M. 2018. Ophiorrhiza jacobii (Rubiaceae) sp. nov. from Western Ghats, India. Nordic J Bot. 36:E01519. https:// doi.org/10.1111/njb.01519

Hareesh VS, Sreekumar VB, Prabhukumar KM, Nirmesh TK, Sreejith KA. 2015a. Ophiorrhiza sahyadriensis (Rubiaceae), a new species from Southern Western Ghats, Kerala, India. Phytotaxa. 202:219-224. https:// doi.org/10.11646/phytotaxa.202.3.6

Hareesh VS, Sreekumar VB, Prabhukumar KM, Sabu M, Sreejith KA. 2015b. Lectotypification of Ophiorrhiza heterostyla Dunn and the new record of O. rugosa var. angustifolia (Thwaites) Ridsdale (Rubiaceae) for India. Webbia. 70: 109-112. https://doi.org/10.1080/0 0837792.2015.1015249

IUCN. 2012. IUCN Red List Categories and Criteria: Version 3.1. Second Edition. International Union for Conservation of Nature and Natural Resources. Gland, Switzerland and Cambridge, UK. p. 1-32

Khan AES, Santhosh Kumar ES, Pushpangadan P. 1998. A new species of Ophiorrhiza L. (Rubiaceae) from, Kerala, India. J Bombay Nat Hist Soc. 95:317-318.

Lo HS. 1990. Taxonomic revision of the Chinese species of Ophiorrhiza (Rubiaceae). Bull Bot Res. 10:1-82.

Nayar TS, Beegam AR, Sibi M. 2014. Flowering Plants of the Western Ghats, India. Jawaharlal Nehru Tropical Botanic Garden and Research Institute, Thiruvananthapuram. Vol. 1, p. 794-797.

Ramamurthy K, Rajan R. 1985. A new species of Ophiorrhiza L. (Rubiaceae) from, Kerala state, India. J Bombay Nat Hist Soc. 82:174-176.

Rajan R, Varghese SC, Kurup R, Gopalakrishnan R, Venkataraman R, Satheeshkumar K, Baby S. 2016. HPTLC-based quantification of camptothecin in Ophiorrhiza species of the southern Western Ghats in India. Cogent Chemistry. 2(1):1275408. http://dx.doi. org/10.1080/23312009.2016.1275408

Tao C, Taylor CM. 2011. Ophiorrhiza. In: Wu ZY, Raven PH, Hong DY (Eds.) Flora of China. (Cucurbitaceae through Valerianaceae, with Annonaceae and Berberidaceae). Beijing: Science Press, and St Louis: Missouri Botanical Garden Press. Vol. 19, p. 258-282

WCSP. 2019. 'World Checklist of Selected Plant Families' Facilitated by the Royal Botanic Gardens, Kew. Published on the Internet; http://wcsp.science.kew.org/ Retrieved 14 March 2020. 